\title{
Opsoclonus and polymyoclonia complicating oat-cell carcinoma of the bronchus
}

\author{
BRYAN D. SHEINMAN* \\ B.Pharm., M.B., B.S., M.R.C.P. \\ JEFFREY GAWLER \\ B.Sc. M.B., B.S., M.R.C.P. \\ Department of Neurological Sciences, St Bartholomew's Hospital, West Smithfield, London ECI
}

\begin{abstract}
Summary
Opsoclonus, with or without polymyoclonia, is a rare syndrome. We report a case associated with an 'oatcell' carcinoma of the bronchus. There is only one previous similar case reported in the world literature.
\end{abstract}

\section{Introduction}

Opsoclonus, originally described by Orzechowski (1927), may be defined as continuous irregular, chaotic, conjugate eye movement in all directions (Smith and Walsh, 1960). Often, although not invariably, it occurs in conjunction with myoclonic movements affecting the head and limbs. The syndrome has been reported most frequently among infants and children (Smith and Walsh, 1960; Cogan, 1954; Marmion and Sandilands, 1947; Kinsbourne, 1962; Baringer, Sweeney and Winkler 1968; Dyken and Kolar, 1968; Kennedy and Tucker, 1962; Bolthauser, Deonna and Hirt, 1979) although these accounts and others do include a few adult cases (Bolthauser et al., 1979; McLean, 1970). The aetiology often remains uncertain although a viral infection has frequently been suggested when there has been a prodromal upper respiratory tract infection or minor febrile illness. Sometimes the cerebro-spinal fluid (CSF) has contained excessive lymphocytes. Serological evidence of infection has only been given in isolated cases; mumps virus (Baringer et al., 1968), St Louis encephalitis virus (Estrim, 1977) and psittacosis (Blue, Janeway and Stanley, 1971).

Solomon and Chutorian (1968) were the first to describe opsoclonus in association with an occult neuroblastoma of childhood and since then there have been many similar reports (Bolthauser et al., 1979) confirming this relationship. Although isolated cases have been reported in association with such diverse condition as vertebro-basilar ischaemia (Bri-

\footnotetext{
*Present address: Royal Free Hospital, Pond Street, London NW3.
}

chet et al., 1970), prolonged post-traumatic coma (Tarrazzi et al., 1977) and an infiltrating glioblastoma (Keane and Devereaux, 1974), there are few reports of extra-cranial tumours other than neuroblastoma in association with opsoclonus. To date carcinoma of the uterus (Allesi, 1940), adenocarcinoma of the breast (Ellenberger, Justinian and Netsky, 1968) and an undifferentiated carcinoma of the bronchus (Ross and Zeman 1967) have been noted. We report a further case associated with 'oat-cell' carcinoma of the bronchus.

\section{Case report}

A fifty-nine-year-old woman presented with vertigo of sudden onset sufficiently severe to prevent her from walking. Apart from lethargy during the preceding two weeks there had been no prodromal illness. Prochlorperazine had been advised by her general practitioner but there had been no improvement and she had become increasingly unwell with vertigo and nausea.

On admission she was distressed and striking involuntary eye movements were apparent in association with myoclonic jerking of the limbs. She was fully orientated and there was no evidence of intellectual deterioration. The fundal appearances were normal. There was continuous, conjugate, chaotic movement of the eyes which was unaffected by her attempts at fixation. Movements persisted when her eyes were closed and they were also observed during sleep. Intermittent myoclonic movement was apparent in the limbs and was exacerbated by their use. When she attempted to sit, her chaotic eye movements became more rapid and myoclonic jerking of the head and trunk was visible. There was no weakness or alteration of tone in the limbs but voluntary movements were ataxic. All the deep reflexes were present and symmetrical and the plantar responses were flexor. There was no sensory 
loss. The neck was not stiff and Kernig's sign was negative. She was afebrile and there were no abnormal signs on general examination.

\section{Investigations}

Blood count, erythrocyte sedimentation rate, urea, electrolytes, liver function, thyroid function, chest Xray, skull $X$-ray and electroencephalogram were all normal. Serological tests for syphilis were negative and paired sera screening for common viral antibodies gave no evidence for infection. The visual evoked responses were unrecordable as fixation was impossible. The cerebrospinal fluid contained 7 lymphocytes $/ \mathrm{ml}$ but the protein and sugar values were normal. Computed tomography (CT) of the brain revealed no abnormality.

Her abnormal eye movement and myoclonus failed to respond to a variety of drugs; prochlorperazine, cinnarizine, carbamazepine, sodium valproate, diazepam, primidone and finally prednisolone $60 \mathrm{mg}$ per day for 13 days. She deteriorated with a declining level of awareness and a virtual cessation of speech. She became incontinent of urine and faeces. Three weeks after admission she developed signs to suggest a chest infection and this was confirmed by a chest $X$ ray which also demonstrated a left hilar mass for the first time. Fibreoptic bronchoscopy revealed a fungating lesion in the left main bronchus and a biopsy showed this to be an oat-cell carcinoma. A few days later she died and regrettably permission for a postmortem was refused.

\section{Discussion}

Opsoclonus is rare. Orzechowski (1927) in his original description suggested that the responsible lesion lay in the mid-brain. The few cases which have come to post-mortem have generally shown changes in the cerebellum, cerebellar nuclei or mesencephalon. Ross and Zeman (1967) found medullary astrocytic and microglial proliferation in the olivary and pontine nuclei together with diffuse neuronal loss of cerebellar Purkinje cells in their study of a patient with opsoclonus associated with carcinoma of the bronchus. The site of neurological damage in our patient remains speculative but the cerebrospinal fluid findings support an inflammatory process. We suggest the addition of opsoclonus with polymyoclonia to the extensive list of non-metastatic manifestations of bronchial cancer on the nervous system.

\section{References}

Allesi, D. (1940) Lesioni parenchimatosis del cervelletto da carcinoma uterino. Rivista di Patologia Nervosa e Mentale, 55, 443.

BARINGER, J.R., SWEenEY, V.P. \& WINKLER, J.F. (1968) Ocular oscillations and opsoclonus. Brain, 91, 473.

BluE, S.K., JANEWAY, R. \& STANLeY, J.A. (1971) Opsoclonus with body tremulousness: a case report with a suggested cause. Transactions of the American Neurological Association, 96, 208.

Bolthauser, E., DeONNA, T.H. \& HIRT, H.R. (1979) Myoclonic encephalopathy of infants or 'dancing eyes syndrome'. Report of seven cases with long term follow-up and review of literature (cases with and without neuroblastoma). Helvetica paediatrica Acta, 34, 119.

BRICHET, B., ANDRE, J.M., RENY, A. \& WEBER, M., (1970) Electromyographic study of opsoclonus occurring in vertebrobasilar insufficiency. Electroencephalography and Clinical Neurophysiology, 29, 534.

CoGAN, D.G. (1954) Ocular dysmetria, flutter-like oscillations of the eyes and opsoclonus. Archives of Ophthalmology, 51, 318.

DYKEN, P. \& KOLAR, O. (1968) Dancing eyes, dancing feet: infantile polymyoclonia. Brain, 91, 305.

Ellenberger, C., Justiniano, F.C. \& Netsky, M.G. (1968) Opsoclonus and parenchymatous degeneration of the cerebellum. Neurology (Minneapolis), 18, 1041.

EsTRIM, W.J. (1977) The serological diagnosis of St-Louis encephalitis in a patient with the syndrome of opsoclonia, body tremulousness and benign encephalitis. Annals of Neurology, 1 , 596.

KeANe, J.R. \& Devereaux, M.W. (1974) Opsoclonus associated with an intracranial tumour. Archives of Ophthalmology, 92, 443.

KENNEDY, C. \& TUCKER, S.A. (1962) Ocular myoclonus: a clinical and pathological study. Neurology (Minneapolis), 12, 297.

KINSBOURNE, M. (1962) Acute myoclonic encephalopathy of infants. Journal of Neurology, Neurosurgery and Psychiatry, 25, 271.

MARMION, D.E. \& SANDILANDS, J. (1947) Opsoclonus, Lancet, ii, 508.

MCLEAN, D.R. (1970) Polymyoclonia with opsoclonus. Neurology (Minneapolis), 20, 508.

ORZECHOWSKI, C. (1927) De l'ataxie dysmetrique des yeux. Journal fur Psychologie und Neurologie, 35, 1.

ROSS, A.T. \& ZEMAN, W. (1967) Opsoclonus, occult carcinoma and chemical pathology in the dentate nucleus. Archives of Neurology, $17,546$.

SMITH, J.L. \& WALSH, F.B. (1960) Opsoclonus-ataxic conjugate movements of the eyes. Archives of Ophthalmology, 64, 244.

Solomon, G.E. \& ChUTORIAN, A.M. (1968) Opsoclonus and occult neuroblastoma. New England Journal of Medicine, 279, 475.

TARrazi, S., AleXANDre, A., Bricolo, A. \& Rizzuto, N. (1977) Opsoclonus and palatal myoclonus during prolonged posttraumatic coma - a clinico-pathologic study. European Neurology (Basel), 15, (5), 257. 